\title{
Current Approaches in Breast Cancer Treatment
}

\author{
Meme Kanseri Tedavisindeki Güncel Yaklaşımlar
}

Pelin İrem Sert ${ }^{1}$

ORCID: 0000-0002-8573-1691

Tuba Tüylü Küçükk1lınç2*

ORCID: 0000-0003-1566-0717

${ }^{1}$ Hacettepe University, Faculty of Pharmacy, 06100, Ankara, Turkey

${ }^{2}$ Hacettepe University, Faculty of Pharmacy, Department of Biochemistry,

Corresponding author: Tuba Tüylü Küçükkılınç Hacettepe University, Faculty of Pharmacy, Department of Biochemistry, 06100, Ankara, Turkey Tel: +903123051499 Fax: +903123114777

E-mail: ttuylu@hacettepe.edu.tr

\section{ABSTRACT}

Cancer is the most common type of cancer in women. Many genetic and environmental factors play an important role in breast cancer and therefore it is considered as a heterogeneous disease. Nowadays, new treatment approaches are being studied for reasons such as the different treatment responses of the defined subtypes to each other, the development of resistance to traditional therapies in clinical use, the high rate of relapse after treatment, and the damage to healthy cells by the chemotherapeutics. Current approaches in breast cancer treatment such as immunotherapy, PI3K / AKT / mTOR inhibitors, JAK / STAT inhibitors, CDK4 / 6 inhibitors target signaling pathways that play a role in breast cancer development and / or contribute to the development of resistance.

Keywords: Breast cancer, drug resistance, signal pathway, inhibitor, new treatment approaches

\section{ÖZET}

Meme Kanseri kadınlarda en sık görülen kanser tipidir. Meme kanserinde pek çok genetik ve çevresel faktörler rol oynamaktadır ve bu nedenle heterojen bir hastalık olarak değerlendirilmektedir. Tanımlanmış olan alt tiplerinin tedaviye verdikleri yanıtın birbirlerinden farklı olması, klinik kullanımda yer alan geleneksel tedavilere karşı direnç gelişmesi, tedaviden sonra nüks oranlarının yüksek olması, kullanılan kemoterapötiklerin aynı zamanda sağlıklı hücrelere de zarar vermesi gibi nedenlerle günümüzde yeni tedavi yaklaşımları üzerinde çalışılmaktadır. Meme kanseri tedavisindeki immünoterapi, PI3K/Akt/mTOR inhibitörleri, JAK/STAT inhibitörleri, CDK4/6 inhibitörleri gibi güncel yaklaşımlar meme kanseri gelişimde rol oynayan ve/veya direnç gelişimine katkıda bulunan sinyal yolaklarını hedef almaktadır.

Anahtar kelimeler: Meme kanseri, ilaç direnci, sinyal yolağı, inhibitörler, yeni tedavi yaklaşımları 


\section{Giriş}

Meme kanseri kadınlarda en sık gözlenen kanser türüdür. Meme kanseri kadınlarda görülen kanserlerin \%30' unu oluşturması ile kadınlarda en sık görülen kanser tipidir. Kadınlarda kansere bağlı ölüm nedenlerinin \% 15'i meme kanserinden kaynaklanmaktadır [1]. Yaş, en önemli risk faktörüdür ve insidans yaş ile birlikte artmasına rağmen, genç kadınlarda daha agresif seyretmektedir. Meme kanserlerinde BRCA1, BRCA2, p53 ve PTEN gibi gen mutasyonları daha çok ailesel meme kanseri öykülerinde gözlenmektedir. Bu gen mutasyonları meme kanseri için oldukça yüksek bir risk oluşturmalarına rağmen tüm meme kanseri vakalarının küçük bir kısmında görülmektedir. Bunun yanı sıra erken yaşta adet görme, uzun süreli oral kontraseptif kullanımı, hormon replasman tedavisi, geç menapoz, hiç doğum yapmama (nuliparite), emzirmeme, alkol tüketimi, obezite ve egzersiz eksikliği de meme kanserini arttıran diğer risk faktörlerindendir [2]. Meme kanserinde pek çok mutasyonun bulunması, epigenetik ve transkripsiyonel değişikliklerin olması, kullanılan tedavilere direnç gelişmesi, tedaviye yanıtın bireysel farklılıklar göstermesi nedeniyle alternatif tedaviler üzerine odaklanılmaktadır. Kemoterapi, radyoterapi gibi geleneksel tedavilerinin yanı sıra kontrol noktası inhibitörleri, meme kanseri aşıları, PI3K/Akt/mTOR inhibitörleri, Histon deasetilaz (HDAC) inhibitörleri, JAK/STAT inhibitörleri, reseptör tirozin kinaz inhibitörleri, androjen reseptör inhibitörleri, Poli ADP riboz polimeraz (PARP) inhibitörleri, siklin bağımlı kinazlar 4 ve $6(C D K 4 / 6)$ inhibitörleri, steroid sülfataz inhibitörleri, farnesil transferaz inhibitörleri (FTI), SRC inhibitörleri ve nanoteknolojik yaklaşımlar güncel tedaviler arasında yer almaktadır [37]. Bu güncel tedavi yaklaşımlarının temeli, meme kanserinde önemli rol oynadığı bilinen sinyal yolaklarının inhibe edilmesi, doğrudan tümör ve tümör mikroçevresinin ve ekspresyon düzeyleri değişen proteinlerin hedeflenmesine dayanmaktadır [6].

\subsection{Meme Kanseri Moleküler Alt Tipleri}

Meme kanseri luminal, insan epidermal büyüme faktörü pozitif (HER2 +), bazal-benzeri, klaudin düşük ve normal benzeri olmak üzere alttiplere ayrilır [8].

Meme kanserlerinin yaklaşık \% 75'inde ER (östrojen reseptörü) ve/veya PR (progesteron reseptörü) pozitiftir. Lümen epitel hücrelerinin tipik proteinlerini kodlayan çeşitli genleri eksprese eder, bu nedenle bu alt tip lümen grubu olarak adlandırılır. Bu grup meme kanserleri luminal A ve luminal B olmak üzere ikiye ayrılır [8]. Luminal A en yaygın alt tiptir ve tüm meme kanserlerinin \% 50-60'ını oluşturur. Bu tümörler sıklıkla düşük histolojik dereceye sahiptirler, iyi prognozludur ve nüks oranı diğer alt tiplere göre düşüktür. Luminal A alt tipi, negatif HER2 ve düşük Ki67 (proliferasyon hücre nükleer antijeni) indeksine sahip ER-pozitif ve/veya PR-pozitif tümörler olarak tanımlanır. Tedavi esas olarak hormonal tedaviye dayanmaktadır $[8,9]$. Luminal B alt tipi ise meme kanserlerinin \%10-20'sini oluşturur. İmmünohistokimyasal açıdan luminal B alt tipi ER+, HER2negatif ve Ki 67 yüksek veya ER ve HER-2+ tümörler olarak tanımlanır. Luminal A alt tipine kiyasla daha yüksek bir nüks oranına, relaps sonrası daha düşük hayatta kalma oranlarına, agresif bir fenotipe, daha yüksek histolojik dereceye, proliferatif indekse ve daha kötü prognoza sahiptir. Tedavi yaklaşımında kemoterapi ve hormonal tedavi yer almaktadır. Anti HER2 tedavisine ise iyi yanıt vermektedir $[9,10]$.

HER2-pozitif meme kanseri alt tiplerinin \% 1520'sini oluşturur. Bu alt tipinde ER ve PR ekspresyonu yoktur, HER-2 amplifikasyonu ve/veya yüksek HER2 ekspresyonu yer almaktadır. Anti HER-2 tedavisine yanıt verir [8].

Bazal benzeri alt tip tüm meme kanserlerinin $\% 15$ ile \% 20'sini temsil eder. ER, PR, HER-2 negatiftir. Üçlü negatif (Triple negatif) olarak da tanımlanabilmektedir. 40 yaşından küçük afrikalı-amerikalı kadınlarda ve BRCA1 gen mutasyonu olan kadınlarda görülme sıklığ 1 daha fazladır. Bu grup tümörler en agresif gruplardan biridir ve prognozları kötü ilerlemektedir. Bu alt tip kemoterapiye iyi yanıt vermektedir $[8,9]$.

Klaudin düşük alt tipi meme kanserlerinin \% 1214'ünü oluşturmaktadır. Klaudin-3, -4, -7, okludin ve E-kaderin de dahil olmak üzere tight junctions ve hücreler arası yapışmada rol oynayan genlerin düşük ekspresyonu ile karakterizedir. Klaudin düşük tipi, hücre proliferasyonu ile ilgili genlerin düşük bir ekspresyonu sergilemelerine rağmen, kötü bir prognoza sahiptir [8].

Normal benzeri alt tip ise tüm meme karsinomlar1nın yaklaşık \% 5-10' unu oluşturur. ER, PR ve HER2 ekspresyonundan yoksun olduklarından, bu tümörler üçlü negatif olarak da sınıflandırılabilir, ancak nadir 
olmaları nedeniyle bu alt tiple ilgili az sayıda çalışma vardır [8].

\section{Meme Kanserinde Sinyal Yolaklarının Önemi}

Kanser hücrelerinde hücre çoğalmasını, bölünmesini, hücre ölümünü, hücre farklılaşmasını, göç mekanizmasını kontrol eden sinyal yolaklarında epigenetik ve genetik değişiklikler meydana gelmektedir. Normal meme bezi gelişimi ve meme kanseri kök hücre fonksiyonlarını düzenleyen çeşitli sinyal yolaklarında, HER2 sinyalizasyonunda ve östrojen reseptör sinyalizasyonunda meydana gelen mutasyonlarının da meme kanseri gelişiminde önemli bir rol oynadığı belirtilmektedir [11, 12].

İnsan epidermal büyüme faktörü reseptörleri (EGFR»ler veya HER»ler) bir tirozin kinaz reseptör ailesidir. Hem normal dokularda hem de birçok kanser türünde ekspre edilmektedirler [13]. HER ailesinin 4 üyesi tanımlanmıştır. Bunlar; HER1 (EGFR, erbB1), HER2 (erbB2, HER2/neu), HER3 (erbB3) ve HER4 (erbB4) 'dir. Meme kanseri dahil pek çok solid tümörde özellikle HER2'nin amplifikasyonu ve/veya aşırı ekspresyonu bulunmaktadır. HER2 hücre büyümesi, hücre farklılaşması, büyümesi ve hayatta kalmasıyla ilgili sinyal yolaklarında önemli rol oynamaktadır ve bu nedenle kanserlerde agresif fenotip olması nedeniyle terapötik bir hedef haline gelmektedir [14].

HER2 diğer HER reseptörleriyle heterodimerizasyon yaparak sinyal iletiminin başlatılmasına katk1 sağlamaktadır [14]. Ligand bağlanmasının ardından meydana gelen dimerizasyonla HER2'nin hücre içindeki domainin tirozin kalıntıları fosforilenir, fos- forilenmenin ardından mitojenle aktive olan protein kinaz (MAPK) ve fosfatidilinositol 4,5-bifosfat $3 \mathrm{ki}$ naz (PI3K) gibi çoklu downstream sinyal yollarının aktivasyonuna yol açar [13].

Pl3K/AKT sinyal yolağı hücre ölümü, hücre proliferasyonu, hücre iskeleti düzenlenmesi ve enerji metabolizmasında önemli rol oynamaktadır [15]. PI3K, bir heterodimerdir ve p110 katalitik kinaz subuniti ile adaptör/regülatuar p85 subunit'lerinden oluşur. PI3K RHO, RAC, protein kinaz C, mutasyonlu RAS ve SRC gibi proteinlerin p85 ile etkileşimi sonucunda aktifleşir. Aktifleşen p110 çeşitli moleküllerle etkileşerek AKT 'nin fosforillenmesine ve aktif hale gelmesini sağlar. Aktif haldeki AKT çeşitli mediyatörle etkileşerek hücre proliferasyonuna katk1 sağlar. Bu yolak üzerinde yer alan çeşitli mediyatörlerde meydana gelen mutasyonların da meme kanseri ile ilişkisi olduğu bilinmektedir [16].

ER sinyal yolu ise, hücre proliferasyonu, invazyon, apoptoz ve anjiyogenez gibi çeşitli fonksiyonları kontrol eden karmaşık bir biyolojik yoldur. Meme kanseri hücreleri östrojen tarafindan yönlendirilen bu yolu hayatta kalmak için kullanırlar [17]. Östrojen reseptörleri (ER'ler) nükleer östrojen reseptörlerinden (ERa, ERb) ve membran östrojen reseptörlerinden oluşmaktadır. Membran östrojen reseptörleri çoğunlukla $G$ proteini bağlı reseptörlerdir. Hem ERa hem de ERb, ligand bağlanması ile ilgili hedef genlerin ekspresyonunu aktive eden veya baskılayan transkripsiyonel faktörlerdir. Her iki reseptörde hedef genlerin ER dimerlerinin ve östrojen yanıt elemanlarının etkileşimine aracılık eden DNA bağlanma alanına sahiptir [18]. Östrojene bağlandıktan sonra, ER başka bir reseptör monomeri ile dimerize olur ve DNA üzerindeki belirli bölgelere çekirdek baskılayıcıları ve koaktivatörlerinin bir

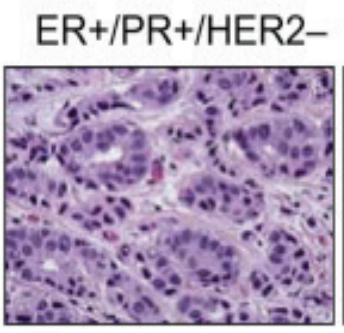

Luminal A

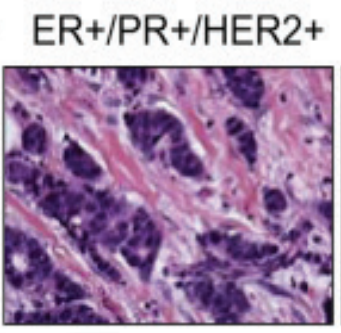

Luminal B

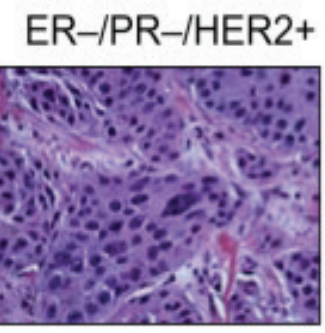

HER2+

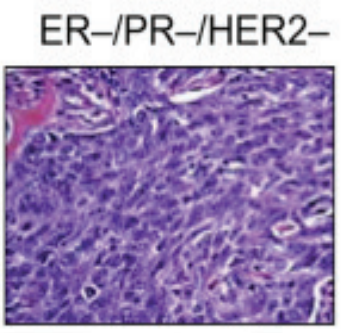

Triple Negatif

Şekil 1.1. Meme kanserinde moleküler alt tiplerin histolojik görüntüsü [10] 
kompleksini oluşturur [19]. ER ayrıca, AP-1 (aktivatör protein-1) ve SP-1 (özgüllük proteini-1) gibi diğer transkripsiyon faktörlerine DNA üzerindeki spesifik bölgelerinde bağlanabilir ve böylece bir ortak regülatör olarak işlev görebilir [19]. Ortak regülatörler, reseptörün transkripsiyonel aktivitesini azaltarak veya artırarak hassas bir mekanizma olarak görev almaktadırlar [20].

Meme kanserlerinin yaklaşık \% 75'i östrojen reseptörünü eksprese eder ve bu tür ER pozitif (ER+) olarak tanımlanmaktadır [9]. Bu nedenle ERa meme kanserlerinin patogenezinde önemli bir rol oynamaktadır. ERa siklin D1 ile etkileşime girerek meme tümör hücrelerinin büyümesini arttırmaktadır [18]. Siklin D1 ise sikline bağımlı kinazlar (CDK'ler) 4 ve 6'nın önemli bir aktivatörüdür. Siklin bağımlı kinazlar (CDK) 4 ve 6 birçok kanser hücresinde hücre döngüsünün $\mathrm{Gl}$ 'den $\mathrm{S}$ fazına geçişini koordine ederler [21]. ERa ve siklin D1'in feedback döngüsü içindeki sinerjizmin anti-östrojen tedavisine karşı gelişen dirençte rol oynadığı düşünülmektedir ve ER + hastalarında hormonal terapi ajanı ve seçimli CDK4/6'nın kombine kullanımına olanak sağlamaktadır [22].

\section{Meme Kanserinde Tedavi Yaklaşımları}

Meme kanseri tedavisi, tümörün bulunduğu bölgenin cerrahi olarak çıkarılması, radyasyon tedavisinin uygulanması ve tümörün boyutu, lenf nodu tutulumunun olup olmaması, reseptör ekspresyonu gibi özellikler göz önünde bulundurularak sistotoksik kemoterapi, endokrin tedavisi ve immünoterapi gibi çeşitli tedavi yaklaşımları uygulanarak gerçekleştirilmektedir .

\section{1. Kemoterapi}

Kemoterapide amaç kanser hücrelerinin öldürülmesi veya çoğalmasının kontrol edilmesidir. Tedavinin etkinliği tümörün alt tipine, kullanılan ilaçlara ve dozuna bağlı olarak değişkenlik göstermektedir [23]. Kemoterapide antrasiklinler, taksanlar, vinca alkaloidleri, kapesitabin, eribulin, gemsitabin ve platin tuzları gibi pek çok kemoterapötik ajan bulunmaktadır. (Tablo1)

\subsection{Endokrin Tedavisi}

\subsubsection{Seçici Östrojen Reseptör Modülatörleri}

Seçici östrojen reseptör modülatörleri (SERMs) hormon reseptör antagonistleri olarak hareket ederler ve kanser hücrelerinde proliferasyonu durdurmak üzere östrojenle yarışarak östrojen bağlanma bölgelerine bağlanırlar. Tamoksifen ve toremifen gibi SERM'Ler $\mathrm{HR}+$ meme kanseri tedavisinde kullanılan en yaygın tedavilerdir [24].

Meme kanseri teşhisi konan hastaların bazıları endokrin tedavisine dirençlidir. $\mathrm{Bu}$ direncin ESR1 genindeki veya efektörlerindeki mutasyonların antiöstrojen ilaçlara karşı kazanılmış dirençle ilişkili olabileceği düşünülmektedir. Örneğin, D538G veya Y537S/C/N mutasyonlarının, östrojen reseptörü 1'in ligand bağlanma alanında konformasyon değişikliğine neden olduğu, bu da tamoksifene olan afiniteyi

Tablo 1. Meme kanserinde kullanılan kemoteröpatikler

\begin{tabular}{|c|c|c|}
\hline Grup & Etki Mekanizması & Etkin Madde Örnekleri \\
\hline Antrasiklinler & $\begin{array}{l}\text { DNA'da topoizomeraz II enzim inhibisyonu ve interkalasyonunun } \\
\text { sağlayarak hücre döngüsünü S fazı ve mitoz sırasında bloke } \\
\text { ederler [24]. }\end{array}$ & $\begin{array}{l}\text { Epirubisin } \\
\text { Doksorubisin }\end{array}$ \\
\hline Taksanlar & $\begin{array}{l}\text { Mikrotübüllerin toplanmasını arttırırlar. Hücre döngüsünü G2 } \\
\text { fazında veya M fazında bloke ederler }[24,25] \text {. }\end{array}$ & $\begin{array}{l}\text { Paklitaksel } \\
\text { Dosetaksel }\end{array}$ \\
\hline Vinca Alkoloidleri & $\begin{array}{l}\text { Tübülinin polimerizasyonunu inhibe eder ve G2-M fazında mitozu } \\
\text { bloke eder. }\end{array}$ & Vinorelbin \\
\hline Antimetabolitler & $\begin{array}{l}\text { Hücre içinde aktif olan 5-FU'e dönüştürülür. 5-FU, urasil ile } \\
\text { yapısal benzerliğe sahiptir ve bu benzerlik sayesinde urasil yerine } \\
\text { RNA১ya 5-FU katılır. Timiditat sentetazı inhibe eder [24]. }\end{array}$ & Kapesitabin \\
\hline Antimetabolitler & $\begin{array}{l}\text { DNA replikasyonu sirasında sitidinin yerini alır ve DNA sentezini } \\
\text { inhibe eder [26]. }\end{array}$ & Gemsitabin \\
\hline Platin Analogları & $\begin{array}{l}\text { DNA zincirinin içinde ve zincirler arasında çapraz bağlanmalar } \\
\text { oluşturarak DNA sentezine engel olur [27]. }\end{array}$ & $\begin{array}{l}\text { Sisplatin } \\
\text { Karboplatin }\end{array}$ \\
\hline
\end{tabular}


düşürdüğ̈̈ ve tamoksifenin hastalı̆̆ın tedavisinde etkisiz hale gelmesine neden olduğu bulunmuştur. Ayrıca bu konformasyon değişikliği hormon uyarımı olmaksızın hücre proliferasyonuna ve tümör progresyonuna da neden olmaktadır [28]. Bunun yanı sıra hücreler, tamoksifen tarafından gerçekleştirilen östrojen sinyal blokajını atlatmak için alternatif yollar kullanarak uyarlanabilir yanıtlar geliştirbilirler. Örneğin fosfataz ve tensin homologu (PTEN) gibi tümör baskılayıcılarının down regülasyonunun $\mathrm{ER}+$ tümörde PI3K/AKT'nin fosforilasyonunu artırarak tamoksifen direnci ile sonuçlandığı gösterilmiştir $[29,30]$.

\subsubsection{Aromataz İnhibitörleri}

Yağ dokusu ve kas gibi periferal dokularda aromataz enzimi tarafindan 4-androstene-3,17-dion (androstenedion) ve testosteronun aromatizasyonu menopozol kadınlarda önemli bir östrojen kaynağı sağlamaktadır [31]. Tedavide kullanılan aromataz inhibitörleri de östrojen sentezini bu yolla inhibe ederler. Aromataz inhibitörleri post menapozol kadınlarda HR+ meme kanseri tedavisinde ilk seçenek olarak kabul edilmektedir [24]. Steroid ve steroid olmayan olmak üzere iki sınıfa ayrılırlar. Anastrozol ve letrozol gibi nonsteroid aromataz inhibitörleri aromataz enziminin aktif bölgesine bağlanmak için endojen ligandlar; androstendion ve testosteron ile yarışır. Nonsteroid aromataz inhibitörlerinin aromataz enzimiyle yaptıkları bu bağlanma güçlü olsa da reversibldır. Anastrozol ve letrozol etkinlikleri birbirine benzer olmak ile birlikte letrozol kas-iskelet sistemi yan etkileri açısından anastrozole göre daha iyi bir yan etki profiline sahipken anastrozole tedavide letrozole kiyasla küçük ama anlamlı bir sağkalım avantajına sahiptir [32]. Ekzemestan ise steroid aromataz inhibitörüdür ve aromataz enziminin aktif bölgesi ile irreversibl olarak bağ yapar ve ilacın kan dolaşımından atılmasindan sonra bile metabolitleri sayesinde aromatazın kalıcı inaktivasyonuna neden olmaktadır [33].

\subsubsection{Selektif östrojen reseptör}

\section{downregülatörleri (SERDs)}

Selektif östrojen reseptör downregülatörleri (SERDs), östrojen reseptörlerine bağlanarak östrojen bağlanma bölgesini bloke ederler. SERD'ler östrojen reseptörlerini tamamen etkisiz hale getiriler ve yok ederler [34]. SERD olan fulvestrant post mena- pozol metastatik meme kanserlerinde veya yumurtalık ablasyonu yapılmış pre menapozol hastalarda kullanılmaktadır [35].

\subsection{Anti-anjiyogenik Tedavi}

Anjiyogenez meme kanseri tümör gelişiminde ve metastazda önemli rol oynamaktadır. Kan kaynağının bulunmadığı durumlarda tümör büyüyemez, sistemik dolaşımla bağlantının olması da hematojen metastaik yayılmayı mümkün kılmaktadır. Anjiyogenez tümör tarafından üretilen maddeler yoluyla uyarılmaktadır ve bu anjiyojenik aktivatörlerinde tümör gelişiminde önemli rol oynadığı düşünülmektedir [36]. Anti-anjiogenik tedavi yaklaşımlarından biri, monoklonal antikor bevacizumab kullanılarak vasküler endotelyal büyüme faktörünün (VEGF) bloke edilmesidir. Bir diğer tedavi yaklaşımı ise sunitib ve sorafenib gibi tirozin kinaz inhibitörleri ile VEGF reseptörünün sinyal transdüksiyonun inhibe edilmesidir [37]. Sunitinib, tip I ATP- kompetitif bir tirozin kinaz inhibitörüdür ve ATP'ye benzer bir hidrojen bağının sunumu yoluyla reseptörler üzerindeki ATP bölgesine bağlanarak VEGFR ve platelet kaynaklı büyüme faktörü reseptörünü (PDGFR) inhibe eder ve böylece sinyal transdüksiyonun önler. Sorafenib ise tip II tirozin kinaz inhibitörüdür. Etkisini ATP bağlanma yerine doğrudan bitişik olan hidrofobik bölgeye bağlanarak inaktif VEGFR, PDGRF, Raf ve KIT kinaz reseptörlerini hedefler böylece dolaylı olarak ATP ile yarışır ve bu kinaz hedeflerinin fosforilasyonunu önler [37]. Pazopanib ise hidrojen bağları oluşturarak ATP ile rekabet eder ve böylece VEGFR ve PDGFR gibi hedef kinaz reseptörlerinin aktivasyonunu inhibe eder [38]. Tirozin kinaz inhibitörlerinin en yaygın yan etkileri ishal, yorgunluk, el-ayak sendromu, hipertansiyon, stomatit, hipotirodizm ve miyelotoksisitedir [39].

\subsection{Immünoterapi}

\subsubsection{Meme Kanseri Așıları}

Meme kanseri tedavisinde kullanılan radyoterapi, kemoterapi gibi geleneksel tedavilerinin doku özgüllüğünün olmaması, hayatta kalma oranlarının düşük olması, ilaç direncinin gelişmesi gibi dezavantajları bulunmaktadır. Bu nedenle meme kanserinde alternatif tedavilere ihtiyaç duyulmaktadır. Bu alternatif tedavilerden biri meme kanseri aşılarıdır. DNA aş1- 
ları, tümörle ilişkili peptit veya protein aşıları, hücre bazlı aşılar ve aşı preparatlarının immünojenitesini iyileştiren rekombinant viral veya bakteriyel vektörler kanser tedavisinde kullanılan aşı yaklaşımlarındandır [40].

Gen bazlı aşı tedavisinin temeli fonksiyonel terapötik proteinlerin üretiminin sağlanması amaciyla hedef hücreye fonksiyonel bir genin verilmesidir. Hücreye verilen bu gen metastaik hücrelerin gelişimini inhibe edebilir, yeni damar oluşumunu bloke edebilir, tümör hücresinin doğrudan inhibe edebilir ya da hücre dögüsünü bloke edebilir ve apoptozu indükleyebilir [41]. İlgili genin hücreye etkili bir şekilde taşınması için virüsler ve bakteriler gibi biyolojik ajanlar veya plasmid DNA'nın memeli hücrelerine sokulmasına yönelik kimyasal ve fiziksel yaklaşımlar gibi biyolojik olmayan ajanlar kullanılabilir.

Biyolojik yaklaşımda kullanılan vektörlerden biri virüslerdir. Virüsler genetik materyalleri, konakçı hücrelerde ekspresyonları için herhangi bir transgeni taşıyacak şekilde tasarlanabilir. Birçok rekombinant virüs, antijen sunan hücreler (APC'ler), özellikle dendritik hücreler (DC'ler) gibi bağışıklık hücrelerinde transgeni enfekte edebilir ve eksprese edebilir. Böylelikle, tümör antijenlerinin bağışıklık sistemine daha fazla sunulması, aşı vektörü tarafindan eksprese edilen antijenlerle tümör hücrelerini hedefleyen sitotoksik T-lenfositlerin artan sıklığına ve aviditesine yol açar [42].

Kemoterapötik ajanlara duyarlı olmamaları, uzak bölgedeki tümörlere erişebilmeleri ve tümör hücrelerinde metabolik olarak aktif olmaları nedeniyle bakteriyel vektörler de meme kanseri aş1 tedavisinde tercih edilmektedirler [43]. Kullanılan en yaygin bakteri türleri, Listeria monocytogenes Bifidobacterium longum, Clostridium acetobutylicum, Salmonella typhimurium Clostridiumnovyi, Bifidobacterium adolescentis ve Escherichia coli'dir [4446]. Sitotoksik proteinleri / immünojenik peptitleri eksprese eden bakteriyel vektörler konakçı kanser hücrelerini öldürmek için kullanılmaktadır. Örneğin MHC sinif I peptit p60217-225'i kodlayan DNA sekanslı S. Typhimurium, CD8 + hücre arac1lı antijene özgü tümör inhibisyonu yoluyla kanser hücrelerini öldürebilir [47]. Zayıflatılmış S. Typhimurium'un kanser hücrelerinde apoptotik hücre ölümünü indükleyen pro-apoptotik proteinlerden biri olan tümör nekroz faktörü ile ilgili apoptozu indükleyen ligand (TRAIL)'1 eksprese ederek tümör büyümesinin azalttığı gösterilmiştir[48].
Peptit bazlı aşılar tek bir antijene veya birden çok antijene karşı bağışıklık tepkisi oluşturmalarına göre tek değerlikli veya çok değerlikli olarak sınıflandırılabilir. Kullanılan antijenler tümör hücrelerinde aşırı eksprese edilen antijenlerdir. Meme kanserinde kullanılan peptit aşılarından biri Nelipepimut-S olarak da bilinen E75 peptid aşısıdır. HER2 proteininin hücre dışı bileşeninden türetilen E75 peptidinden oluşur ve sitotoksik CD8 + T hücre yanıtını uyaran tek değerli bir peptid aşısıdır [49].

Hücre temelli aşılar hastadan veya bir donör kaynaklı immün hücrelerinin ya da tümörünün modifiye hücreler veya tüm hücre komponentlerini oluşturarak immün yanın indüklenmesine dayanır. Hücre bazlı aşılar tek değerlikli peptit aşılar ile karşılaştırıldığında bağışıklık sisteminin daha kapsamlı aktivasyonuna neden olurlar [50].

\subsubsection{Monoklonal Antikorlar}

Klinik uygulamada en yaygın kullanılan ve onaylanmış kanser immünoterapi yöntemi monoklonal antikorlardır [51].

Monoklonal antikorlar immünoterapötik etkilerini üç ana mekanizma ile gerçekleştirir. Bunlar;

- Kanser hücreleri tarafindan bölünme ve anjiogenezde kullanılan sinyal yolaklarını aktive eden faktörlere ve reseptörlerine bağlanarak inhibe ederek,

- Spesifik tümör ilişkili antijenlere bağlanan kimerik veya insan antikor bileşenlerinden oluşan hedef monoklonal antikor ilişkili antikora bağımlı hücresel sitotoksisite (ADCC)

- Kompleman aktivasyonu ile kompleman bağım11 sitotoksisite oluşturarak gerçekleştirmektedir (CDC) [52].

ADCC mekanizmasında, monoklonal antikor önce tümör hücreleri gibi hedef hücrelerin yüzeyindeki antijenlere bağlanır ve daha sonra makrofajlar ve doğal öldürücü (NK) hücreler gibi bağışıklık hücrelerinin Fc reseptörleri, hücreye bağlı monoklonal antikorları tanır. Reseptörlerin çapraz bağlanması, perforin ve granzim gibi sitotoksik ajanlar ile, tümör hücrelerinin apoptozuna neden olur [53].

Trastuzumab HER2 reseptörüne bağlanarak hücre bölünmesinin G1 fazında durdurulmasını sağlar ve HER2+ meme kanser vakalarında kullanılmaktadır 
[14]. Hastaların bir kısmında trastuzumaba karşı direnç gelişmektedir. $\mathrm{Bu}$ direnç mekanizmalarından biri epitop maskelemesiyle trastuzumabin HER2 reseptörüne bağlanmasının engellenmesidir. Büyük bir zara sabitlenmiş glikoprotein olan Müsin 4 (MUC 4) ve CD44/hyaluronan polimer kompleksi HER2 + kanserlerinde epitopu maskeleyebilen ve dolayısıyla ilaç bağlanma sürecini değiştirebilen iki önemli proteindir. Bu iki protein aktive edildiğinde, trastuzumabın HER2 reseptörüne bağlanma etkinliğinin normal hücrelerdekinin yaklaşık \% 20'sine düştüğü gözlenmiştir [54]. Bir diğer direnç mekanizması ise down stream sinyal yollarının değişmesidir. ErbB ailesinin diğer üyelerinin aktivasyonu veya artan heterodimer oluşumu gibi bazı down stream yollarının up regülasyonu, trastuzumabın neden olduğu HER2 sinyal blokajının baypas edilmesine neden olabilir. $\mathrm{Bu}$ durumda, dimer oluşumunu bloke eden başka bir monoklonal antikor olan pertuzumab ile veya bir HER2 dimer tirozin kinaz inhibitörü olan lapatinib ile kombinasyon tedavisi, hastanın HER2 hedefleme tedavisine yanıtını eski haline getirebilir $[14,55]$. Bu direnç gelişime karşı geliştirilen bir tedavi yaklaşımı ise PI3K/AKT/mTOR sinyal yolağı inhibitörleridir.

CDC mekanizmasında ise monoklonal antikorlar, hedef hücrede membran yüzey antijenlerine bağlanır ve multiple yolaklar komplemanın monoklonal antikorlara bağlandığı bir kompleman kaskadı ortaya çıkarır. Kompleman bağlanması, bir membran saldırı kompleksinin indüksiyonuna yol açar ve aktive edilmiş kompleman sistemi hedef hücreyi lizise uğratır [56].

\subsubsection{Kontrol Noktası Ínhibitörleri}

Tümör hücreleri antitümör immün tepkilerini inhibe etmek için çoklu immün düzenleyici mekanizmalar kullanırlar. Bu mekanizmalardan biri immün kontrol noktaları olarak da bilinen inhibitör reseptörlerin aş1r1 ekspresyonudur. Programlanmış Hücre Ölümü-1 (PD-1) ve Sitotoksik T lenfositle ilişkili molekül-4 (CTLA-4) T hücreleride eksprese edilen iki immünomodülatör reseptördür ve immün baskılamaya arac1l1k ederler. [57]. PD-1 insanlarda ve farelerde aktive edilmiş monositler, dendritik hücreler, T hücreleri, $\mathrm{B}$ hücreleri ve doğal öldürücü $\mathrm{T}$ hücreleri üzerinde eksprese edilen ana immün kontrol noktası reseptörüdür. PD-1 hücre yapışması, çoğalması ve sitokin sinyalleşmesinde önemli bir rol oynar. PD-L1 ve PD-L2 olmak üzere iki ligandı bulunmaktadır. PD-
L1 ve PD-L2 ekspresyonu kanser hücreleri bağışıklık sistemi tarafindan saldırıya uğradığında artar. $\mathrm{Bu}$ da T hücrelerinin baskılanmasına ve immün kaçışına yol açar [58]. Meme kanserinde PD-L1 ekspresyonunun yüksek olması yüksek proliferatif indeks, yüksek histolojik derece ve artmış tümör boyutu gibi çeşitli negatif prognostik faktörlerle ilişkili olduğu düşünülmektedir [59]. Kanser hücrelerine karşı bağışıklık tepkisini arttırmak amaciyla PD-1 ve PD-L1 arasındaki etkileşimin bloke edilmesi kanser tedavisine yönelik yaklaşımlardan biridir [60]. Meme kanserinde PD-1'e karşı kullanılan antikorlar Atezolizumab, Pembrolizumab ve Avelumab'dır [61]. CTLA-4 ise T hücresi aktivasyonundan kısa bir süre sonra up regüle edilir, CD28 ko-stimülasyonuna negatif feedback sağlamak için CD80/CD86'ya bağlanır ve bağışıklık tepkisinin hazırlanma fazı sırasında $T$ hücresi aktivasyonunu sınırlar. $\mathrm{Bu}$, kontrolsüz bağışıklığın önlenmesine yardımcı olur. Klinikte tremelimumab ve Ipilimumab olmak üzere CTLA-4'e özgü iki hümanize monoklonal antikor bulunmaktadır [62].

\subsection{Nanopartikül Temelli Tedavi Yaklaşımları}

Nanopartiküller normal hücrelere zarar vermeden kanserli hücrelerde yüksek kemoterapötik dozlarda bulunan veya terapötik genleri hedefleyen modifiye ilaç taşıyıcı sistemlerdir. Nanopartiküller hedefe yönelik olmaları nedeniyle ilaç direncinin üstesinden gelmeleri, diğer dokulara dağılımlarının az olması ve tümör hücrelerinde birikimlerinin fazla olması, ciddi sistemik yan etkilerinin az görülmesi, uzun süre kan dolaşımında kalmaları, suda çözünürlüğü düşük ilaçların taşınmasına olanak sağlamaları gibi özellikler açısından geleneksel ilaç tedavilerine göre daha üstündür. Miseller, lipozomlar polimerler, dendrimerler,altın nanopartiküller ve nanojeller kanser tedavisinde ilaç taşıyıcı sistemler olarak kullanılmaktadır [63].

\subsection{Yeni Tedavi Yaklaşımları}

Hücre sağkalımı ve proliferasyonunun düzenlenmesinde önemli bir rol oynayan PI3K/Akt/mTOR yolağının meme kanseride dahil pek çok kanser türünde etkili olduğu düşünülmektedir [6].

Yolaktaki PIK3CA, AKT1, AKT2 ve PTEN, PI3K/ Akt gibi temel genler mutasyona uğramaktadır. $\mathrm{Bu}$ genler meme kanserlerinin \%70'den fazlasında ak- 
tive olmaktadır [16]. Ayrıca PI3K/Akt/mTOR sinyal yolağının anormal aktivasyonunun HER2 aşırı eksprese eden meme kanserinde endokrin ve trastuzumab direncinde rol oynadığı bilinmektedir. Bu sinyal yolağının inhibitörlerinin dirençli hücrelerde trastuzumab ile kombinasyonunun antikanser aktiviteyi daha etkin hale getirebileceği düşünülmektedir [29]. $\mathrm{Bu}$ sebeple PI3K/Akt/mTOR yolunu hedefleyen farkl1 stratejilerin meme kanseri tedavisinde önemli olduğu belirtilmektedir.

Janus kinaz (JAK) ile sinyal dönüştürücüleri ve transkripsiyon aktivatörleri (STAT), hücre proliferasyonunda yer alan yollara katılır. Janus kinazlar STAT transkripsiyon faktörlerini aktive eden sitoplazmik kuyruğa bağlanan, siklinler D1, D2 ve E gibi hücre döngüsü düzenleyicilerinin ekspresyonunu uyarır. JAK2/STAT5 aktivasyonu, meme kanseri hücre dizilerinde PI3K/mTOR inhibisyonuna karş1 dirençle ilişkilendirilirken IL6/JAK2/STAT3 yolu, meme kanseri hücrelerinin proliferasyonunda ve metastatik yayılmasinda rol oynar $[68,69]$.

DNA transkripsiyonu etkileyen histon deasetilaz enzimi aynı zamanda ER ekspresyonunda da rol oynamaktadır. Bazı meme kanseri hastalarında ER reseptör ekspresyonu olmadığından, endokrin terapisine karşı direnç gelişmektedir. Bu tümörlerde Era baskılanmasına histon deasetililasyonu gibi epigenetik modifikasyonların aracılık ettiği düşünülmektedir.Histon deasetilaz inhibitörleri kullanılarak ER $\alpha$ ve aromataz ekspresyonunun up regüle edilerek tümör hücrelerinin hormonal tedaviye yanıt vermesi sağlanabilir [70].

Bir başka tedavi yaklaşımı ise çeşitli sinyal yolaklarında veya reseptör ailelerinde yer alan reseptör tirozin kinazların inhibe edilmesine dayanır. Hedef alınan tirozin kinazlarından biri HER ailesidir. HER ailesinin oluşturduğu diğer heterodimerlerden veya homodimerlerden daha aktif olan HER2 / HER3 heterodimerlerinin aşırı ekspresyonunun trastuzumab direncine neden olduğu bildirilmiştir [14]. Bu nedenle, HER ailesi reseptörlerinin daha geniş bir inhibisyonuyla, tek başına trastuzumabtan daha fazla antikanser etkisi ortaya çıkarılabilir. HER1 / HER2 / HER4'ün geri döndürülemez bir tirozin kinaz inhibitörü olan Neratinib'in HER2 + meme kanserinde trastuzumab bazlı adjuvan tedaviden sonra 2 y1llık invazif hastalıksız sağkalımı önemli ölçüde iyileştirdiği bildirilmiştir [73].

Androjen reseptörü (AR), nükleer reseptör süper ailesine ait steroid hormonla aktive edilen bir transkripsiyon faktörüdür. Son zamanlarda AR sinyali meme kanserinde hem bir prognostik belirteç hem de potansiyel terapötik hedef olarak daha önemli bir hale gelmiştir. AR esas olarak androjenlere bağlanır, çekirdeğe girer ve androjene yanıt veren genlerin transkripsiyonunu uyarır. Yapılan çalışmalarda AR/ FOXA1/ $\beta$-katenin kompleksinin ERBB3 geninin düzenleyici bölgelerine bağlandığını ve ER-/ HER2+ meme kanseri hücrelerinde büyümeyi indüklediğini göstermektedir [76].

PARP'ler, gen regülasyonu, kromatinin yeniden şekillenmesi, DNA onarımı ve apoptoz dahil olmak üzere bazı hücresel süreçlerde yüksek oranda rol oynayan bir nükleoprotein ailesidir. DNA onarım sürecinin inhibisyonu hücre ölümüne yol açabilir ve bu, PARP inhibitörlerini antikanser tedavisi için mükemmel bir hedef haline getirir [77].

CDK4/6, siklin D1 ile tersinir etkileşimleri ile hücre

Tablo 3.1. PI3K/Akt/mTOR sinyal yolağını hedef alan güncel tedavi yaklaşımları

\begin{tabular}{|c|c|c|c|c|}
\hline Etkin Madde & Etki Mekanizması & Meme Kanseri Tipi & Kombinasyonda Kullanılan İlaçlar & Faz \\
\hline Pictilisib & PI3K inhibitörü & ER+ & $\begin{array}{c}\text { Paklitaksel }+(-) \\
\text { Bevacizumab/ Trastuzumab }+ \\
\text { Letrozol }\end{array}$ & Faz Ib [64] \\
\hline Buparlisib & PI3K inhibitörü & $\mathrm{ER}+$ & Fulvestrant & III [65] \\
\hline Taselisib & PI3K inhibitörü & HER2-/HR+ & Fulvestrant & II[3] \\
\hline Capivasertib & Akt inhibitörü & TNMK & Paklitaksel & III [66] \\
\hline Everolimus & mTOR inhibitörü & $\mathrm{HR}+/$ Metastatik & Eksemestan & $\begin{array}{c}\text { Onaylı } \\
{[67]}\end{array}$ \\
\hline Bimiralisib & $\begin{array}{l}\mathrm{PI} 3 \mathrm{~K} / \mathrm{mTOR} \\
\text { inhibitörü }\end{array}$ & TNMK & Eribulin & $\mathrm{Ib} / \mathrm{II}[6]$ \\
\hline
\end{tabular}


Tablo 3.2. Sinyal yolaklarına etki eden güncel tedavi yaklaşımları I

\begin{tabular}{|c|c|c|c|c|}
\hline Etkin Madde & Etki Mekanizması & Meme Kanseri Tipi & $\begin{array}{c}\text { Kombinasyonda Kullanılan } \\
\text { İlaçlar }\end{array}$ & Faz \\
\hline Ruxolitinib & JAK/STAT İnhibitörü & $\begin{array}{l}\text { MetastatikHER2 } \\
\text { HER2 + ve TNMK }\end{array}$ & $\begin{array}{l}\text { Kapesitabin } \\
\text { Paklitaksel+ } \\
\text { doksorubisin }\end{array}$ & $\begin{array}{l}\text { II [5] } \\
\text { II [6] }\end{array}$ \\
\hline Entinostat Vorinostat & HDAC İnhibitörü & $\mathrm{HR}+$ & $\begin{array}{l}\text { Eksemestan } \\
\text { Tamoksifen }\end{array}$ & $\begin{array}{l}\text { III [71] } \\
\text { II [72] }\end{array}$ \\
\hline Neratinib & $\begin{array}{l}\text { Tirozin Kinaz } \\
\text { İnhibitörü }\end{array}$ & HER 2+ & - & Onaylı [73] \\
\hline $\begin{array}{l}\text { Bikalutamid } \\
\text { Enzalutamid }\end{array}$ & $\begin{array}{l}\text { Androjen Reseptör } \\
\text { Antagonisti }\end{array}$ & $\begin{array}{l}\mathrm{Er}+/ \mathrm{HER}- \\
\quad \mathrm{HR}+\end{array}$ & $\begin{array}{l}\text { Fulvestrant } \\
\text { Eksemestan }\end{array}$ & $\begin{array}{l}\text { II [7] } \\
\text { II [74] }\end{array}$ \\
\hline Olaparib & PARP İnhibitörleri & TNMK & - & $\begin{array}{c}\text { Onayl1 } \\
{[75]}\end{array}$ \\
\hline
\end{tabular}

döngüsünü düzenler. Hormonal direnç geliştiğinde bile, tümörler proliferasyon için hala CDK4 / 6-siklin D1'e bağımlıdır [22]. Bu nedenle, hormonal tedavi ve CDK4/6 inhibitörü kombinasyonu ile tedavisi sonrasinda HR + /HER2- meme kanserinde daha belirgin G1-S hücre döngüsü durması gözlenmiştir. CDK4/6 inhibitörleri, retinoblastoma proteininin fosforilasyonunu bloke ederek çalışır, böylece G1-S bloke edilmesine aracılık etmek için E2F-yanıt genlerini down regüle ederler. Ayrıca hücre proliferasyonunu inhibe etmek için transkripsiyon faktörü Forkhead box protein M1'i defosforile ederler [78].

Steroid sülfataz, inaktif sülfatla konjuge steroidlerin aktif ve östrojenik konjuge olmayan formlara dönüşümünü düzenleyen anahtar bir enzimdir. Steroid sülfatazın ekspresyon seviyesi ve enzim aktivitesi ER $\alpha$-pozitif meme kanserinde önemli ölçüde arttığ 1 bulunmuştur [83]. Bu nedenle steroid sülfatazın inhibisyonu ile meme kanseri hücrelerinin büyümesini uyarabilen östrojenik steroidleri azaltılması amaçlanmaktadır [80].

Farnesil Transferaz İnhibitörleri (FTI); Lonafarnib, spesifik bir FTI olarak, farnesilasyon yoluyla Ras fonksiyonunu inhibe eder. RAS mutasyonları meme kanserinde yaygın olmamasına rağmen son zamanlarda FTI üzerinde çalışmalar yapılmaktadır [81].

Src, hücre proliferasyonu, hücre farklılaşması, göç, anjiyogenez ve hayatta kalma gibi çoklu biyolojik fonksiyonlarla iligili sinyal yolaklarında yer alan bir proto-onkojendir. Bu nedenle Src'nin tümör oluşumu ve ilerlemesinde anahtar bir rol oynadığı düşünülmektedir[84]. Hücre hattı çalışmalarında dasatinib (SRC dahil çoklu tirozin kinazların inhibitörü), setuksimab (anti-EGFR monoklonal antikor) ve cisplatin ile birleştirildiğinde, bir TNMK hücre dizileri panelinde sinerjistik antikanser aktivitesi gözlenmiştir. Üç ilaç kombinasyonu, tekli veya iki ilaçlı kombinasyondan daha belirgin apoptoz indüksiyonu ve EGFR ve MAPK fosforilasyonunun inhibisyonunu sağladığ1 gözlenmiştir. Buna ek olarak kanser hücresi göçü ve istilası, TNMK hücre dizilerinde tek başına dasatinib tedavisi veya dasatinib içeren kombinasyon tedavisi ile önemli ölçüde inhibe edilmiştir. Bu nedenle, tümörleri hem EGFR hem de c-Src'yi birlikte aşırı eksprese eden TNBC hastalarında dasatinib içeren kombinasyonların kullanımını araştırmak için klinik çalışmalara ihtiyaç duyulmaktadır [85].

\section{Sonuç}

Meme kanseri kadınlarda kansere bağlı ölümlerde ikinci sırada yer almaktadır. Tedavide amaç hastalara tedaviden maksimum fayda sağlarken nüksü, direnci ve toksik etkileri en aza indirme veya ortadan kaldırma ve aynı zamanda hastaların iyi bir yaşam kalitesine sahip olmalarını sağlamaktır. Tedavisindeki en büyük zorluklardan biri ise terapötik yaklaşımların seçiminde önemli rol oynayan meme kanserinin heterojen yapısıdır. Klinik yanıt, heterojen yapısı nedeniyle farklı meme kanseri alt tipleri arasında büyük ölçüde değişiklik göstermektedir. Pek çok alt tipinin bulunmas1, meydana gelen genetik, epigenetik, translasyonel değişiklikler nedeniyle meme kanseri tedavisinde standart tek bir tedavi yaklaşımı bulunmamaktadır. Bunun yanı sıra mevcut tedavi yaklaşımlarına karşı gelişen direnç, tümörün tedavi sonrası nüks etmesi gibi nedenlerle yeni tedavi yaklaşımları geliştirilmeye çalışılmaktadır. Bu amaçla sağlıklı dokuya zarar vermeden, tümör dokusunu hedefleyebilen nanopartikül temelli taşıyıcılar, direnç gelişimine aracılık eden sinyal yolaklarının 
Tablo 3.3. Sinyal yolaklarına etki eden güncel tedavi yaklaşımları II

\begin{tabular}{|c|c|c|c|c|}
\hline Etkin Madde & Etki Mekanizması & Meme Kanseri Tipi & $\begin{array}{c}\text { Kombinasyonda Kullanılan } \\
\text { İlaçlar }\end{array}$ & Faz \\
\hline Palbociclib & CDK4 ve 6 İnhibitörü & $\mathrm{HR}+/$ HER2+ & Aromataz İnhibitörleri & Onaylı [79] \\
\hline İrosustat & $\begin{array}{l}\text { Steroid Sülfataz } \\
\text { İnhibitörleri }\end{array}$ & ER+ & Aromataz İnhibitörleri & II [80] \\
\hline Lonafarnib & $\begin{array}{c}\text { Farnesil Transferaz } \\
\text { İnhibitörü }\end{array}$ & HER 2+ & $\begin{array}{c}\text { Trastuzumab } \\
+ \\
\text { paklitaksel }\end{array}$ & I [81] \\
\hline Dasatinib & SRC İnhibitörü & $\mathrm{TNBC}$ & Paklitaksel & Preklinik [82] \\
\hline
\end{tabular}

inhibe edilmesi, her farklı direnç mekanizmasına yanit olabilecek tedavi stratejilerinin ve spesifik moleküler alt tiplerinin tedavisi için PI3K/AKT /mTOR, CDK4/6 inhibitörleri, tirozin kinaz inhibitörleri veya immün kontrol noktası gibi yeni hedefli ajanların geliştirilmesi gerekmektedir.

\section{Kaynaklar}

1. Siegel RL, Miller KD, Jemal A: Cancer Statistics. Cancer Journal for Clinicians 2020, 70(1):7-30.

2. McPherson K, Steel CM, Dixon JM: Breast cancer-epidemiology, risk factors, and genetics. British Medical Journal 2000 , 321(7261):624-628.

3. Dickler MN, Saura C, Richards DA, Krop IE, Cervantes A, Bedard PL, Patel MR, Pusztai L, Oliveira M, Cardenas AK, Cui N, Wilson TR, Stout TJ, Wei MC, Hsu JY, Baselga J: Phase II Study of Taselisib (GDC-0032) in Combination with Fulvestrant in Patients with HER2-Negative, Hormone ReceptorPositive Advanced Breast Cancer. Clinical Cancer Research 2018, 24(18):4380-4387.

4. Yardley DA, Ismail-Khan RR, Melichar B, Lichinitser M, Munster PN, Klein PM, Cruickshank S, Miller KD, Lee MJ, Trepel JB: Randomized phase II, double-blind, placebo-controlled study of exemestane with or without entinostat in postmenopausal women with locally recurrent or metastatic estrogen receptor-positive breast cancer progressing on treatment with a nonsteroidal aromatase inhibitor. Journal of Clinical Oncology 2013, 31(17):2128-2135.

5. O'Shaughnessy J, DeMichele A, Ma CX, Richards P, Yardley DA, Wright GS, Kalinsky K, Steis R, Diab S, Kennealey G, Geschwindt R, Jiang W, Rugo HS: A randomized, doubleblind, phase 2 study of ruxolitinib or placebo in combination with capecitabine in patients with advanced HER2-negative breast cancer and elevated C-reactive protein, a marker of systemic inflammation. Breast Cancer Research and Treatment 2018, 170(3):547-557.
6. Godone RLN, Leitao GM, Araújo NB, Castelletti CHM, Lima-Filho JL: Clinical and molecular aspects of breast cancer: Targets and therapies. Biomedicine \& Pharmacotherapy 2018, 106:14-34.

7. Gucalp A, Tolaney S, Isakoff SJ, Ingle JN, Liu MC, Carey LA, Blackwell K, Rugo H, Nabell L, Forero A, Stearns V, Doane AS, Danso M, Moynahan ME, Momen LF, Gonzalez JM, Akh$\operatorname{tar}$ A, Giri DD, Patil S, Feigin KN, Hudis CA, Traina TA: Phase II trial of bicalutamide in patients with androgen receptorpositive, estrogen receptor-negative metastatic Breast Cancer. Clinical Cancer Research 2013, 19(19):5505-5512.

8. Eroles P, Bosch A, Pérez-Fidalgo JA, Ana Lluch: Molecular biology in breast cancer: Intrinsic subtypes and signaling pathways. Cancer Treatment Reviews 2012, 38:698-707.

9. Allison KH: Molecular pathology of breast cancer: what a pathologist needs to know. American Journal of Clinical Pathology 2012, 138(6):770-780.

10. Rivenbark AG, O'Connor S, Coleman WB: Molecular and Cellular Heterogeneity in Breast Cancer Challenges for Personalized Medicine. The American Journal of Pathology 2013, 183(4):1113-1124.

11. Feng Y, Spezia M, Huang S, Yuan C, Zeng Z, Zhang L, Ji Xiaojuan, Liu W, Huang B, Luo W, Liu B, Lei Y, Du S, Vuppalapati A, Luu HH, Haydon RC, He T, Ren G: Breast cancer development and progression:Risk factors, cancer stem cells, signaling,pathways, genomics, and molecular,pathogenesis. Genes \& Diseases 2018, 5(2):77-106.

12. Polack K: Breast cancer: origins and evolution. Journal of Clinical Investigation 2007, 117(11):3155-3163.

13. Burgess AW: EGFR family: structure physiology signalling and therapeutic targets. Growth Factors 2008, 26(5):263-274.

14. Daniele L, Sapino A: Anti-HER2 treatment and breast cancer: state of the art,recent patents, and new strategies. Recent Patents on Anticancer Drug Discovery 2009, 4(1):9-18.

15. Hennessy BT, Smith D, Ram PT, Lu Y, Mills GB: Exploiting the PI3K/AKT pathway for cancer drug discovery. Nature Reviews Drug Discovery 2005, 4(12):988-1004. 
16. Castaneda CA, Cortes-Funes H, Gomez HL, Ciruelos EM: The phosphatidyl inositol 3-kinase/AKT signaling pathway in breast cancer. Cancer Metastasis Reviews 2010, 29(4):751759.

17. Osborne CK, Schiff R: Mechanisms of Endocrine Resistance in Breast Cancer. Annual Review of Medicine 2011, 62:233247.

18. Björnström L, Sjöberg M: Mechanisms of Estrogen Receptor Signaling: Convergence of Genomic and Nongenomic Actions on Target Genes. Molecular Endocrinology 2005, 19(4):833842.

19. Klinge CM: Estrogen receptor interaction with estrogen response elements Nucleic Acids Res 2001, 29(14):2905-2919.

20. Osborne CK, Bardou V, Hopp TA, Chamness GC, Hilsenbeck SG, Fuqua SWA, Wong J, Allred DC, Clark GM, Schiff R: Role of the estrogen receptor coactivator AIB1 (SRC-3) and HER-2/neu in tamoxifen resistance in breast cancer. Journal of National Cancer Institute 2003, 95(5):353-361.

21. Zwijsen RML, Wientjens E, Klompmaker R, Sman van der J, Bernards R, Michalides RJAM: CDK-Independent Activation of Estrogen Receptor by Cyclin D1. Cell 1997, 88(3):405-415.

22. Snah AN, Cristofanilli M: The Growing role of CDK4/6 inhibitors in treating hormone receptor-positive advanced breast cancer. Current Treatment Options in Oncology 2017, 18(1):6.

23. Işık G: Meme kanseri tedavisinde paklitaksel yüklü polikatyonik ve anyonik siklodekstrin nanoküre formülasyonu ve in vitro değerlendirilmesi. Ankara: Hacettepe Üniversitesi; 2013.

24. Tsuji W, Plock JA: Breast Cancer Metastasis. In: Ahmad A (eds), Introduction to Cancer Metastasis. Academic Press; Alabama, Amerika Birleşik Devletleri. 2016: pp. 13-31.

25. Terwogt JMM, Niujen B, Huinink T, Beijnen JH: Alternative Formulation of Paclitaxel. Cancer Treatment Reviews 1997, 23(2):87-95.

26. Carmichael J, Possinger K, Phillip P, Beykirch M, Kerr H, Walling J, Harris AL: Advanced Breast Cancer: A Phase II Trial With Gemcitabine. Journal of Clinical Oncology 1995, 13(11):2731-2736.

27. Cardoso F, Costa A, Norton L, Senkus E, Aapro M, André F, Barrios CH, Bergh J, Biganzoli L, Blackwell KL, Cardoso MJ, Cufer T, Saghir N, Fallowfield L, Fenech D, Francis P, Gelmon K, Giordano SH, Gligorov J, Goldhirsch A, Harbeck N, Housasami N, Hudis C, Kaufman B, Krop I, Kyriakides S, Lin UN, Mayer M, Merjaver SD, Nordström EB, Pagani O, Partridge A, Penault-Llorca F, Piccart MJ, Rugo H, Sledge G, Thomssen C, Vant Veer L, Vorobiof D, Vrieling C, West $\mathrm{N}$, Xu B, Winner E: ESO-ESMO 2nd international consensus guidelines for advanced breast cancer (ABC2). Breast 2014, 23(5):489-502.
28. Robinson DR, Wu Y, Vats P, Su F, Lonigro RJ, Cao X, Kalyana-Sundaram S, Wang R, Ning Y, Hodges L, Gursky A, Siddiqui J, Tomlins SA, Roychowdhury S, Pienta KJ, Kim SY, Roberts JS, Rae JM, Van Poznak CH, Hayes DF, Chugh R, Kunju LP, Talpaz M, Schott AF, Chinnaiyan AM: Activating ESR1 mutations in hormone-resistant metastatic breast cancer. Nature Genetics 2013, 45(12):1446-1451.

29. Tserga A, Chatziandreou I, Michalopoulos NV, Patsouris E, Saetta AA: Mutation of genes of the PI3K/AKT pathway in breast cancer supports their potential importance as biomarker for breast cancer aggressiveness. Virchows Archiv 2016, 469(1):35-43.

30. Raha P, Thomas S, Munster PN: Epigenetic modulation: a novel therapeutic target for overcoming hormonal therapy resistance. Epigenomics 2011, 3(4):451-470.

31. Manni A: Clinical use of aromatase inhibitors in the treatment of breast cancers,. Journal of Cellular Biochemistry 1997, 17:242-246.

32. Kudachadkar R, O'Regan RM: Aromatase inhibitors as adjuvant therapy for postmenopausal patients with early stage breast cancer. CA: Cancer Journal of Clinicians 2005, 55(3):145163.

33. Buzdar AU, Robertson JF, Eiermann W, Nabholtz JM: An overview of the pharmacology and pharmacokinetics of the newer generation aromatase inhibitors anastrozole, letrozole, and exemestane. Cancer 2002, 95(9):2006-2016.

34. Howell A, Osborne CK, Morris C, Wakeling AE: ICI 182,780 (Faslodex): development of a novel, "pure" antiestrogen. Cancer 2000, 89(4):817-825.

35. Di Leo A, Jerusalem G, Petruzelka L, Torres R, Bondarenko IN, Khasanov R, Verhoeven D, Pedrini JL, Smirnova I, Lichinitser MR, Pendergrass K, Garnett S, Lindemann JPO, Sapunar F, Martin M: Results of the CONFIRM phase III trial comparing fulvestrant $250 \mathrm{mg}$ with fulvestrant $500 \mathrm{mg}$ in postmenopausal women with estrogen receptor-positive advanced breast cancer. Journal of Clinical Oncology 2010, 28(30):4594-4600.

36. Folkman J: Tumor Angiogenesis: Therapeutic Implications. The New England Journal of Medicine 1971, 285(21):11821186.

37. Gotink KJ, Verheul HMW: Anti-angiogenic tyrosine kinase inhibitors: what is their mechanism of action? Angiogenesis 2010, 13(1):1-14.

38. Keisner SV, Shah SR: Pazopanib: the newest tyrosine kinase inhibitor for the treatment of advanced or metastatic renal cell carcinoma. Drugs 2011, 71(4):443-454.

39. Aalders KC, Tryfonidis K, Senkus E, Cardoso F: Anti-angiogenic treatment in breast cancer: facts, successes, failures and future perspectives. Cancer Treatment Reviews 2017, 53:98110. 
40. Burke EE, Kodumudi K, Ramamoorthi G, Czerniecki BJ: Vaccine Therapies for Breast Cancer. Surgical Oncology Clinics of Norht America 2019, 28(3):353-367.

41. Santos-Carballal B, Fernandez-Fernandez E, Goycoolea FM: Chitosan in Non-Viral Gene Delivery: Role of Structure, Characterization Methods, and Insights in Cancer and Rare Diseases Therapies. Polymers (Basel) 2018, 10(4):444.

42. Brentville VA, Atabani S, Cook K, Durrant LG: Novel tumour antigens and the development of optimal vaccine design. Therapeutic Advances in Vaccines and Immunotherapy 2018, 6(2):31-47.

43. Kaimala S, Sbiei AA, Cabral-Marques O, Fernandez-Cabezudo MJ, Al-Ramadi BK: Attenuated Bacteria as Immunotherapeutic Tools for Cancer Treatment. Frontiers Oncology 2018, 8:136.

44. Park SH, Zheng JH, Nguyen VH, Jiang SN, Kim DY, Szardenings M, Min JH, Hong Y, Choy HE, Min JJ: RGD Peptide Cell-Surface Display Enhances the Targeting and Therapeutic Efficacy of Attenuated Salmonella-mediated Cancer Therapy. Theranostics 2016, 6(10):1672-1682.

45. Kim SH, Castro F, Paterson Y, Gravekamp C: High efficacy of a Listeria-based vaccine against metastatic breast cancer reveals a dual mode of action. Cancer Research 2009, 69(14):58605866.

46. Shanmugaraj B, Bharathi PL, Mahalakshmi B, Subbiah S, Mei Hue R, Velmurugan BH: Bacterial and viral vectors as vaccine delivery vehicles for breast cancer therapy. Life Sciences 2020, 250:117550

47. Panthel K, Meinel KM, Sevil Domènech V.E, Geginat G, Linkemann K, Busch D.H, Rüssmann H. Prophylactic anti-tumor immunity against a murine fibrosarcoma triggered by the Salmonella type III secretion system. Microbes and Infection 2006, 8:2539-2546.

48. Hu B, Kou L, Li C, Zhu LP, Fan YR, Wu ZW, Wang JJ, Xu GX: Bifidobacterium longum as a delivery system of TRAIL and endostatin cooperates with chemotherapeutic drugs to inhibit hypoxic tumor growth. Cancer Gene Therapy 2009, 16(8):655-663.

49. Milani A, Sangiolo D, Aglietta M, Valabrega G: Recent advances in the development of breast cancer vaccines. Breast Cancer (Dove Med Press) 2014, 6:159-168.

50. Kurtz SL, Ravindranathan S, Zaharoff DA: Current status of autologous breast tumor cell-based vaccines. Expert Reviews of Vaccines 2014, 13(12):1439-1445.

51. Waldmann TA: Immunotherapy: past, present and future. Nature Medicine 2003, 9(3):269-277.

52. Şakalar Ç, İzgi K, Canatan H: Kanser İmmün Terapi ve Monoklonal Antikorlar. Firat Üniversitesi Sağlık Bilimleri Tıp Dergisi 2013, 27(2):105-110.
53. Chávez-Galán L, Arenas-Del Angel MC, Zenteno E, Chávez R, Lascurain R: Cell Death Mechanisms Induced by Cytotoxic Lymphocytes. Cellular \& Molecular Immunology 2009, 6(1):15-25.

54. Nagy P, Friedlander E, Tanner M, Kapanen AI, Carraway KL, Isola J, Jovin TM: Decreased accessibility and lack of activation of ErbB2 in JIMT-1, a herceptin-resistant, MUC4expressing breast cancer cell line. Cancer Research 2005, 15(65):473-482.

55. Nahta R, Esteva F: HER2 therapy: molecular mechanisms of trastuzumab resistance. Breast Cancer Research 2006, $8(6): 215$.

56. Zhou X, Hu W, Qin X: The Role of Complement in the Mechanism of Action of Rituximab for B-Cell Lymphoma: Implications for Therapy. The Oncologist 2008, 13(9):954-966.

57. Kahveci K, Türkoğlu Laçin M: İmmün Kontrol Noktası İnhibitörleri Ctla-4 ve Pd-1/Pd-11'in İmmünoterapideki Yeri. Mehmet Akif Ersoy Üniversitesi Fen Bilimleri Enstitüsü Dergisi 2019, 10(2):210-218.

58. Nallasamy P, Chava S, Verma SS, Mishra S, Gorantla S, Coulter DW, Byrareddy SN, Batra SK, Gupta SC, Challagundla KB: PD-L1, inflammation, non-coding RNAs, and neuroblastoma: Immuno-oncology perspective. Seminars in Cancer Biology 2018, 52(Pt2):53-65.

59. Sabatier R, Finetti P, Mamessier E, Adelaide J, Chaffanet M, Ali HR, Viens P, Caldas C, Birnbaum D, Bertucci F: Prognostic and predictive value of PDL1 expression in breast cancer. Oncotarget 2014, 6(7):5449-5464.

60. Zhang X, Wang C, Wang J, Hu Q, Langworthy B, Ye Y, Sun W, Lin J, Wang T, Fine J, Cheng H, Dotti G, Huang P, Gu Z: PD-1 Blockade Cellular Vesicles for Cancer Immunotherapy. Advanced Materials 2018, 30(22):1-8.

61. Kruse M, Abraham J: Breast Canser. In: Ito F, Ernstoff M(eds), Immune Checkpoint Inhibitors in Cancer. Elsevier; New York, Amerika Birleşik Devletleri. 2019: pp 157-167.

62. Pardoll DM: The blockade of immune checkpoints in cancer immunotherapy. Nature Reviews Cancer 2012, 12(4):252-264.

63. Kumar Singh S, Singh S, W Lillard Jr J, Singh R: Drug delivery approaches for breast cancer. International Journal of Nanomedicine 2017, 12:6205-6218.

64. Schöffski P, Cresta S, Mayer IA, Wildiers H, Damian S, Gendreau S, Rooney I, Morrissey KM, Spoerke JM, Ng VW, Singel SM, Winer E: A phase Ib study of pictilisib (GDC-0941) in combination with paclitaxel, with and without bevacizumab or trastuzumab, and with letrozole in advanced breast cancer. Breast Cancer Research 2018, 20(109).

65. Baselga J, Ah Im S, Iwata H, Cortés J, De Laurentiis M, Jiang Z, Arteaga CL, Jonat W, Clemons M, Ito Y, Awada A, Chia S, Ja- 
giello-Gruszfeld A, Pistilli B, Tseng LM, Hurvitz S, Masuda N, Takahashi M, Vuylsteke P, Hachemi S, Dharan B, Di Tomaso E, Urban P, Massacesi C, Campone M: Buparlisib plus fulvestrant versus placebo plus fulvestrant in postmenopausal, hormone receptor-positive, HER2-negative, advanced breast cancer (BELLE-2): a randomised, double-blind, placebo-controlled, phase 3 trial. The Lancet Oncology 2017, 18(7):904-916.

66. Schmid P, Cortes J, Robson ME, Iwata H, Hegg R, Nechaeva M, Xu B, Verma S, Haddad V, Imedo ER, Schiavon G, Foxley A, Park YH: A phase III trial of capivasertib and paclitaxel in first-line treatment of patients with metastatic triple-negative breast cancer (CAPItello290).Journal of Clinical Oncology 2019, 38(15).

67. Baselga J, Campone M, Piccart M, Burris 3rd HA, Rugo HS, Sahmoud T, Noguchi S, Gnant M, Pritchard KI, Lebrun F, Beck JT, Ito Y, Yardley D, Deleu I, Perez A, Bachelot T, Vittori L, Xu Z, Mukhopadhyay P, Lebwohl D, Hortobagyi GN: Everolimus in postmenopausal hormone-receptor-positive advanced breast cancer. The New England Journal of Medicine 2012, 366(6):520-529.

68. Marotta LLC, Almendo V, Marusyk A, Shipitsin M, Schemme J, Walker SR, Bloushtain-Qimron N, Kim JJ, Choudhury SA, Maruyama R, Wu Z, Gönen M, Mulvey LA, Bessarabova MO, Huh SJ, Silver SJ, Kim SY, Park SY, Lee HE, Anderson KS, Richardson AL, Nikolskaya T, Nikolsky Y, Liu XS, Root DE, Hahn WC, Frank DA, Polyak K: The JAK2/STAT3 signaling pathway is required for growth of CD $44^{+} \mathrm{CD} 24^{-}$stem cell-like breast cancer cells in human tumors. Journal of Clinical Investigation 2011, 121(7):2723-2735.

69. Britschgi A, Andraos R, Brinkhaus H, Klebba I, Romanet V, Müller U, Murakami M, Radimerski T, Bentires-Alj M: JAK2/ STAT5 inhibition circumvents resistance to PI3K/mTOR blockade: a rationale for cotargeting these pathways in metastatic breast cancer. Cancer Cell 2012, 22(6):796-811.

70. Sabnis G, Goloubeva O, Chumsri S, Nguyen N, Sukumar S, Brodie AMH: Functional activation of the estrogen receptor- $\alpha$ and aromatase by the HDAC inhibitor, entinostat, sensitizes of ER-negative tumors to letrozole. Cancer Research 2011, 71(5):1893-1903.

71. Connolly MR, Zhao F, Miller KD, Jung Lee M, Piekarz RL, Smith KL, Brown-Glaberman U, Winn JS, Faller BA, Onitilo AA, Burkard ME, Budd GT, Levine EG, Royce ME, Kaufman PA, Thomas A, Trepel JB, Wolff AC, Sparano JA: Abstract GS4-02: E2112: Randomized phase 3 trial of endocrine therapy plus entinostat/placebo in patients with hormone receptor-positive advanced breast cancer. A trial of the ECOG-ACRIN cancer research group. Cancer Research 2021, 81(4):1-18.

72. Munster PN, Thurn KT, Thomas S, Raha P, Lacevic M, Miller A, Melisko M, Ismail-Khan R, Rugo H, Moasser M, Minton
SE: A phase II study of the histone deacetylase inhibitor vorinostat combined with tamoxifen for the treatment of patients with hormone therapy-resistant breast cancer. British Journal of Cancer 2011, 104(12):1828-1835.

73. Chan A, Delaloge S, Holmes FA, Moy B, Iwata H, Harvey VJ, Robert NJ, Silovski T, Gokmen E, Minckwitz G, Ejlertsen B, Chia SKL, Mansi J, Barrios CH, Gnant M, Buyse M, Gore I, Smith 2nd J, Harker G, Masuda N, Petrakova K, Zotano AG, Iannotti N, Rodriguez G, Tassone P, Wong A, Bryce R, Ye Y, Yao B, Martin M: Neratinib after trastuzumab-based adjuvant therapy in patients with HER2-positive breast cancer (ExteNET): a multicentre, randomised, double-blind, placebo-controlled, phase 3 trial. The Lancet Oncology 2016, 17(3):367377.

74. Krop I, Abramson V, Colleon M, Traina T, Holmes F, GarciaEstevez L, Hart L, Awada A, Zamagni C, Morris PG, Schwartzberg L, Chan S, Gucalp A, Biganzoli L, Steinberg J, Sica L, Trudeau M, Markova D, Tarazi J, Zhu Z, O’Brien T, Kelly CM, Winer E, Yardley D: A Randomized Placebo-Controlled Phase 2 Trial Evaluating Exemestane With or Without Enzalutamide in Patients With Hormone Receptor-positive Breast Cancer. Clinical Trials: Targeted Therapy 2020, 26(23):1-33.

75. FDA approves olaparib for germline BRCA-mutated metastatic breast cancer; 2018 December 1. Avaible from: https:// www.fda.gov/drugs/resources-information-approved-drugs/ fda approves-olaparib-germline-brca-mutated-metastaticbreast-cancer. [Website]

76. Kono M, Fujii T, Lim B, Karuturi MS, Tripathy D, Ueno NT: Androgen Receptor Function and Androgen Receptor-Targeted Therapies in Breast Cancer A Review. JAMA Oncology 2017, 3(9):1266-1273.

77. Jubin T, Kadam A, Jariwala M, Bhat S, Sutariya S, Gani AR, Gautam S, Begum R: The PARP family: insights into functional aspects of poly (ADP-ribose) polymerase-1 in cell growth and survival. Cell Proliferation 2016, 49(4):421-437.

78. Xu H, Yu S, Liu Q, Yuan X, Mani S, Pestell RG, Wu K: Recent advances of highly selective CDK4/6 inhibitors in breast cancer. Journal of Hematology \& Oncology 2017, 10(97):1-12.

79. Finn RS, Martin M, Rugo HS, Jones S, Im SA, Gelmon K, Harbeck N, Lipatov ON, Walshe JM, Moulder S, Gauthier E, Lu DR, Randolph S, Dieras V, Slamon DJ: Palbociclib and Letrozole in Advanced Breast Cancer. The New England Journal of Medicine 2016, 375(20):1925-1936.

80. Palmieri C, Stein RC, Liu X, Hudson E, Nicholas H, Sasano H, Guestini F, Holcombe C, Barrett S, Kenny L, Reed S, Lim A, Hayward L, Howell S, Coombes RC: IRIS study: a phase II study of the steroid sulfatase inhibitor Irosustat when added to an aromatase inhibitor in ER-positive breast cancer patients. Breast Cancer Research Treatment 2017, 165(2):343-353. 
81. Kerklaan BM, Dieras V, Tourneau CL, Mergui-Roelvink M, Huitema ADR, Rosing H, Beijnen JH, Marreaud S, Govaerts AS, Piccart-Gebhart MJ, Schellens JHM, Awada A: Phase I study of lonafarnib (SCH66336) in combination with trastuzumab plus paclitaxel in Her2/neu overexpressing breast cancer: EORTC study 16023. Cancer Chemotherapy Pharmacology 2013,71(1):53-62.

82. Tian J, Raffa F, Dai M, Moamer A, Khadang B, Hachim IY, Bakdounes K, Ali S, Jean- Claude B, Lebrun JJ: Dasatinib sensitises triple negative breast cancer cells to chemotherapy by targeting breast cancer stem cells. British Journal of Cancer 2018, 119(12):1495-1507.
83. Stanway SJ, Delavault P, Purohit A, Lawrence Woo LW, Thurieau C, Potter BVL, Reed MJ: Steroid Sulfatase: A New Target for the Endocrine Therapy of Breast Cancer. Oncologist 2007, 12(4):370-374.

84. Hiscox S, Nicholson R: Src inhibitors in breast cancer therapy. Expert Opinion on Therapeutic Targets 2008, 12(6):757-767.

85. Kim EMH, Mueller K, Gartner E, Boerner J: Dasatinib is synergistic with cetuximab and cisplatin in triple-negative breast cancer cells. Journal of Surgical Research 2013,185(1):231239. 